\title{
The Responsibility of the People's Republic of China for Alleged Human Rights Violations against the Uighurs*
}

\author{
Hashfi Taris** \\ DOI: https://doi.org/10.22304/pjih.v6n3.a10
}

Submitted: December 5, 2019 | Accepted: February 1, 2020

\begin{abstract}
Following the adoption of the Universal Declaration on Human Rights (UDHR) after the World War II, the international community has begun to try to respect and to protect human rights. Among the basic principles in the protection of human rights are the principles of equality and non-discrimination that every human being is considered to be equal without differences. Unfortunately, presently, many human rights violations against minority groups are triggered by differences of ethnicity, religion, race, or language. In 2018, the CERD Committee reported that there were arbitrary arrests of ethnic minority Uighurs in the Xinjiang region of China. A number of reports say that the Chinese government had violated several basic rights of the Uighurs. Several international human rights law conventions have regulated remedies when a state commits a human rights violation. This paper is intended to examine the forms of human rights violations committed against the Uighur minority and the legal remedies that can be done to hold the Chinese state accountable for alleged human rights violations committed.
\end{abstract}

Keywords: Human Rights Violations, State Responsibility, Uighurs

\section{Tanggung Jawab Negara Republik Rakyat Tiongkok terhadap Dugaan Pelanggaran HAM pada Etnis Minoritas Uighur}

\begin{abstract}
Abstrak
Semenjak diadopsinya Universal Declaration on Human Rights (UDHR) pasca Perang Dunia II, masyarakat internasional mulai mencoba menghargai dan melindungi hak asasi manusia (HAM) yang melekat kepada setiap orang. Salah satu prinsip dasar dalam perlindungan hak asasi manusia adalah prinsip persamaan dan non-diskriminasi, yang berarti bahwa setiap manusia dianggap setara tanpa adanya perbedaan. Namun, dewasa ini masih banyak ditemukan pelanggaran HAM yang dilakukan terhadap kelompok minoritas atas dasar perbedaan suku, agama, ras maupun bahasa. Pada tahun 2018, Komite CERD melaporkan bahwa telah terjadi penangkapan sewenang-wenang terhadap etnis minoritas Uighur di wilayah Xinjiang, China. Hingga muncul beberapa laporan yang menyatakan bahwa pemerintah China telah melanggar beberapa hak dasar yang dimiliki oleh etnis Uighur. Beberapa konvensi hukum hak asasi manusia internasional telah mengatur mengenai
\end{abstract}

\footnotetext{
* This article is adopted from minor thesis which has been presented on $14^{\text {th }}$ of January 2020 by the author. The Minor Thesis was under supervision of Dr. Irawati Handayani, S.H., LL.M. and Chloryne Trie Isana Dewi, S.H., LL.M.

** A Graduate of the Law Faculty of Padjadjaran University, Jalan Dipati Ukur No. 35 Bandung, S.H. (Universitas Padjadjaran), tarishashfi@gmail.com
} 
upaya penyelesaian yang dapat dilakukan oleh negara ketika telah terjadi suatu pelanggaran HAM yang dilakukan oleh negara lain. Tulisan ini ditujukan untuk mengkaji bentuk-bentuk pelanggaran HAM yang dilakukan oleh China terhadap kaum minoritas Uighur dan upaya hukum yang dapat dilakukan untuk meminta pertanggungjawaban dari negara China atas dugaan pelanggaran HAM yang dilakukannya.

Kata kunci: Pelanggaran HAM, Tanggung Jawab Negara, Uighur

\section{A. Introduction}

In May 2014, the Chinese government issued a new policy called the "Strike Hard Campaign against Violent Terrorism" in Xinjiang aimed to combat religious extremism and terrorism. ${ }^{1}$ The implementation of the policy is an act of pressing the Uighur minority in Xinjiang. The level of pressure increased dramatically after the Secretary of the Chinese Communist Party, Chen Quanguo, was transferred from the Tibet Autonomous Region to Xinjiang Uighur Autonomous Region (XUAR) at the end of $2016 .^{2}$ Following the transfer, the Chinese authorities have increased the detention against Uighur Muslims who were identified as "enemies of the state". Civilians in the Xinjiang region were arbitrarily arrested and detained so that they were placed in a camp they called "political education camps" or "reeducation camps". ${ }^{3}$

Several UN humanitarian agencies have reported that more than one million people have been detained at the camp. The Muslims who were there, were forced to learn Mandarin, sing praises to the Chinese government and the Chinese Communist Party, and were forced to abandon some aspects of their identity such as culture, religion, and language. ${ }^{4}$ In addition, there are amendments to Xinjiang Regulations on Religious Affairs that have been in force since 1994. These regulations constitute restrictions on religious practices in the Xinjiang region, which in effect restrict the activities carried out by Muslims in Xinjiang. They are (1) prohibition of all forms of appearance which are interpreted as arousing religious fanaticism; (2) the requirement that all pilgrims must be regulated by the state; (3) the restriction of "halal" level to certain food products (meat, milk, and vegetable oil); (4) the prohibition of the distribution of documents relating to religion and ethnic policies that can routinely become public information in other countries, such as draft laws and religious regulations; (5) the prohibition of religious education and punishment for those who cannot stop or report religious

Human Rights Watch, “Eradicating Ideological Viruses: China's Campaign of Repression against Xinjiang's Muslim",https://www.hrw.org/report/2018/09/09/eradicating-ideological-viruses/chinas-campaign-

repression-against-xinjiangs, accessed on September 2019.

2 Human Rights Watch, "World Report 2019: China Events of 2018", https://www.hrw.org/worldreport/2019/country-chapters/china-and-tibet, accessed on September 2019.

lbid.

Ibid. 
activities at school; and (6) the prohibition of children from participating in religious activities and the introduction of religion, including parents and teachers. ${ }^{5}$

Arbitrary detention in the application of the policy is one of the things that need to be considered in determining human rights violations that occur in Xinjiang. Individuals who have been detained by police or authorities will be interrogated and transferred to detention centers or directly transferred to political education camps. ${ }^{6}$ In detention centers, detainees are detained before being tried. They who are not charged or convicted of imprisonment will be sent to political education camps or released. ${ }^{7}$ The detention process carried out by the police is not in accordance with the basic standards of detention procedures and is carried out without regard to reasonable legal protection processes such as providing a detention warrant, establishing an identifiable crime, or allowing access to legal counsel. ${ }^{8}$

The implementation of the Strike Hard Campaign can be said to be a discriminatory act carried out by the Chinese government, because the arrests and detentions made to Uighurs are based on their identity or physical characteristics. ${ }^{9}$ In addition, there are several violations committed by the Chinese government in the political education camps, such as political indoctrination to the compulsion to leave the culture and identity of the Uighurs. The camps carried out a military system for prisoners, wherein each morning prisoners were required to carry out flag ceremonies and sing hymns to President $\mathrm{Xi}$ Jinping and the Chinese Communist Party. ${ }^{10}$ Detainees who cannot use Mandarin are forced to learn Mandarin, even prisoners are not allowed to use their language or say religious greetings (like as-salaam alaikum for Muslims). ${ }^{11}$

In 2018, Gay McDougall, a Special Rapporteur on the UN Committee on Elimination of Racial Discrimination (CERD), reports that more than 1 million Uighurs and other minority Muslims in Xinjiang had been arbitrarily detained. ${ }^{12}$ The report stated that the Chinese government had transformed Xinjiang into an area without rights, in which the Uighurs and Muslims are considered enemies of the state and treated unfairly. ${ }^{13}$ In the development, the report attracted the attention of the international community. On July 10, 2019, 22 countries had signed a joint statement that aims to reprimand China in upholding national law

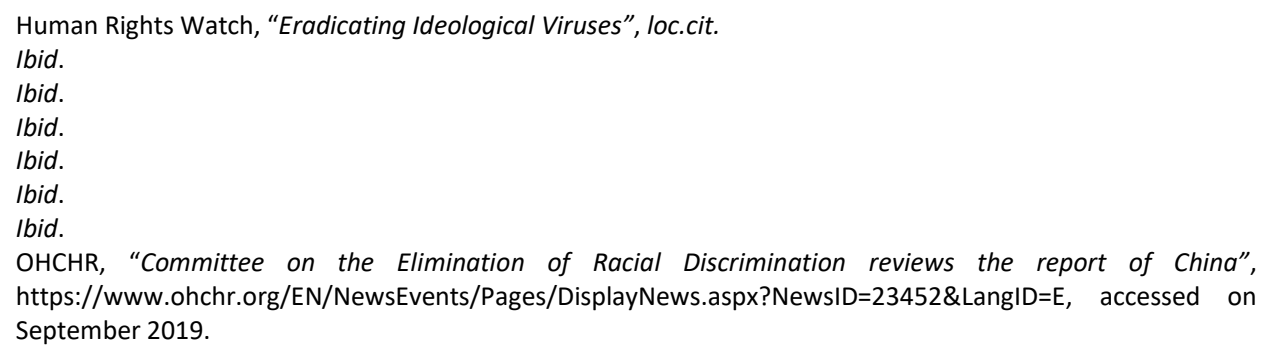
https://www.ohchr.org/EN/NewsEvents/Pages/DisplayNews.aspx?NewsID=23452\&LangID=E, accessed on September 2019.

13 Ibid. 
and international obligations, and respecting human rights and religious freedom in Xinjiang. ${ }^{14}$

Concerning all actions of the Chinese government against the Uighurs, this article discusses the protection of human rights of the Uighurs and the efforts that can be performed by the state to resolve human rights violations.

\section{B. Protection of Human Rights of Minorities}

\section{Sources of International Law on Minority Rights}

The Universal Declaration of Human Rights (UDHR) was adopted by the UN General Assembly as a general standard for human rights that must be upheld by every country without any element of discrimination. ${ }^{15}$ As a statement or charter, the UDHR is only morally binding on countries but the statement is not yet legally binding. However, even if it is not legally binding, the document has enormous moral, political, and educational influence. The UDHR symbolizes the moral commitment of the international community to norms and basic rights. This moral and political influence is evident from his frequent mention in judges' decisions, laws, or constitutions of some states, as well as the United Nations. ${ }^{16}$ Protection of the rights to minorities continues to be developed. Later, the rights to minorities become an inseparable element of universally recognized human rights. ${ }^{17}$

Today, the idea of providing protection for minority rights is supported by several reasons. An opinion states that by protecting the rights of minorities, a state will be able to maintain the stability, democratic security, and peace. ${ }^{18}$ It can be said that the main purpose of the protection of minority rights is to prevent internal conflicts in a country. ${ }^{19}$ Eide identifies three important components in the protection of minorities: (1) respecting the equality of all humans, (2) ensuring the dignity and characteristics of all group diversity, and (3) approaches to promote stability and peace domestically and internationally. ${ }^{20}$ Protection of minorities is an issue that is still being developed in international law and is enforced through bilateral or multilateral international agreements. International law seeks to protect minorities by giving equal rights to providing special protection from minorities. ${ }^{21}$ Minority can be interpreted as a group that is not dominant in a state society. Minorities have different characteristics based on ethnicity, religion, or

14 Human Rights Watch, "UN: Unprecedented Joint Call for China to End Xinjiang Abuses", https://www.hrw.org/news/2019/07/10/un-unprecedented-joint-call-china-end-xinjiang-abuses, accessed on September 2019.

15 Md. Kamruzzaman, Shashi Kanto Das, "The Evolution of Human Rights: An Overview in Historical Perspective", American Journal of Service Science and Management, Volume 3, Issue 2, 2016, p. 5.

Miriam Budiarjo, Dasar-Dasar Ilmu Politik, Jakarta: Gramedia, 1998, p. 124.

Ibid.

Ibid.

Ibid.

Asbjorn Eide, A New Approaches to Minority Protection, London: Minority Rights Group, 1993, p. 12. Emilia Papoutsi, “Minorities Under International Law: How Protected They Are?”, Journal of Social Welfare and Human Rights, Volume 2, Issue 1, 2014, p. 305. 
language. In short it represents a smaller number than the majority population. They are aware of the differences they have and have the desire to maintain it. ${ }^{22}$

Although not explicitly mention of minority protection, the UDHR provides guarantees of freedom of expression, freedom of religion, the right to culture and politics, and equality for all. ${ }^{23}$ Thus, the declaration guarantees equality in society with minorities and protects them from discriminatory acts committed by a state government. $^{24}$ The protection of minorities' interests, such as freedom of expression and religion, is in accordance with the concept of international human rights law to protect important features of humanity from the exercise of sovereign state power. ${ }^{25}$ The right of the minorities was first mentioned in Article 27 of the International Covenant on Civil and Political Rights (ICCPR) as follows,

"In those States in which ethnic, religious or linguistic minorities exist, persons belonging to such minorities shall not be denied the right, in community with the other members of their group, to enjoy their own culture, to profess and practise their own religion, or to use their own language."

Therefore, based on the article, state has an obligation to protect minorities in its territory so that they can maintain their culture, practice their religion, and use their language. In addition to the provision, the UN Declaration on the Rights of Persons Belonging to National or Ethnic, Religious, and Linguistic Minorities (UNDM), which has been adopted by the UN General Assembly, assigns states' obligations to protect the existence and the national's or ethnic's identity, culture, religion and language of the minorities in their territories as well as the conditions to promote the identities. ${ }^{26}$ The UNDM also regulates that minorities have the right to enjoy their own culture, practice their religion, and use their own language. ${ }^{27}$ In addition, minorities should also have the right to participate in cultural, religious, social, economic, and other public life without any discrimination. ${ }^{28}$

The High Commissioner for Human Rights identifies four important areas in the consideration of protection to minorities. They are (1) the protection of the existence of minorities; (2) the protection of the rights of minorities to enjoy their cultural identity and reject forced assimilation; (3) the protection of the principles

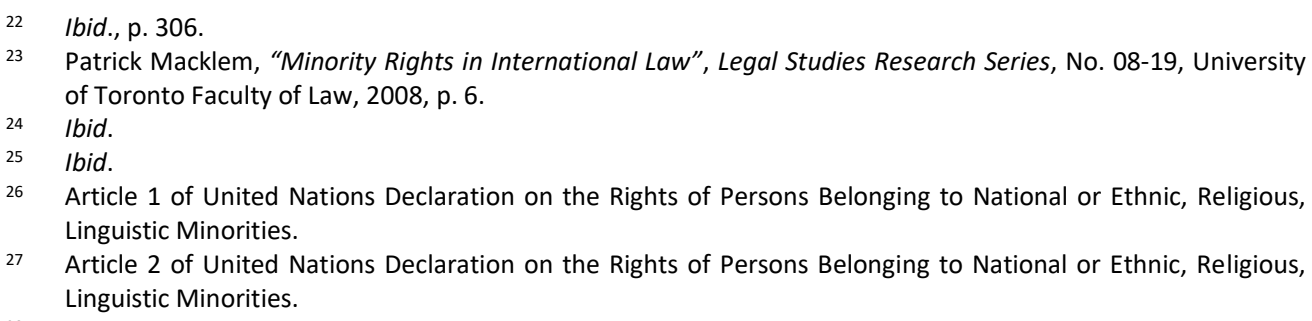


of non-discrimination and equality are effective; and (4) the guarantee that members of minority population can participate in public life. ${ }^{29}$ Therefore, the basic principles that must be maintained in protecting minorities are non-discrimination and equality, in accordance with Articles 2, 26, and 27 of the ICCPR.

\section{Understanding the Concept of Minority}

One of the biggest difficulties in providing protection of the rights of minorities is the determination of the term 'minority'. There is no definition of a minority at any international convention. In 1977, Capotorti provides an understanding that was most generally accepted as follows. ${ }^{30}$

"a group numerically inferior to the rest of the population of a State, in a non-dominant position, whose members - being nationals of the States - possess ethnic, religious or linguistic characteristics differing from those of the rest of the population and show, if only implicitly, a sense of solidarity, directed towards preserving their culture, traditions, religion or language."

The definition was later revised in 1985 by Dechenes. He is a member of the United Nations Sub-Commission on the Prevention of Discrimination and Protection of Minorities. Deschenes defines minority as follows. ${ }^{31}$

"a group of citizens of a state, constituting a numerical minority and in a non-dominant position in that state, endowed with ethnic, religious, or linguistic characteristics which differ from those of the majority of the population, having a sense of solidarity with one another, motivated, If only implicitly, by a collective will to survive and whose aim is to achieve equality with the majority in fact and law."

Both definitions only focus on the concept based on ethnicity, religion, and language. The definitions do not mention 'national minorities'. Until 1992, the UNDM issued a new term for minorities, namely 'national minorities'. Azcarate states that national minority is "what in the last resort constitutes the distinctive and characteristic features of a national minority is the existence of a national consciousness, accompanied by linguistic and cultural differences". ${ }^{32}$

Azcarate explained that language and cultural differences are major factors in determining whether national consciousness lived. Azcarate uses a more flexible approach, which states that there are other factors that must be considered, such

Patrick Macklem, op.cit., pp. 14-15.

30 Francesco Capotorti, Study on the Rights of Persons Belonging to Ethnic, Religious and Linguistic Minorities, New York: UN Human Rights Study, 1991, p. 96.

31 Jules Deschenes, Compilation of Proposals Concerning a Definition of the Term "Minority", Commission on Human Rights, 1986, pp. 19-28.

32 Ulrike Barten, cit., p. 164. 
as race, religion, and historical and geographical factors. However, he further emphasizes that "minorities are responsible for the sense of community, of union, of internal solidarity in the past, present and future, and also for that latent feeling of opposition. ${ }^{33}$

Minorities can be interpreted as a group of people who are different from the majority. The three notions of minority by Azcarate, Capotorti, and Deschenes talk about solidarity and ownership of a community. It is absurd to give special rights to a group of people who do not feel like a group. Thus, minorities only exist when objective and subjective factors have been met. ${ }^{34}$ Referring to the three definitions previously mentioned, the three experts have added the 'link of time' and 'threat link' in the subjective factor of solidarity. Capotorti uses the term 'preserve' or to maintain. In a sense, a minority must have the intention to maintain its existence. At the same time, 'preserving' can also mean that if there is nothing actively done, there will no longer be something called a minority. ${ }^{35}$ Deschenes uses a clearer approach, in which he states 'a collective will to survive'. In this case, the two dimensions of threat and time are clearer. ${ }^{36}$ On the other hand, Azcarate states that it needs a factor of 'internal solidarity in the past, present and future' and the presence of 'latent feeling of opposition'. ${ }^{37}$ Therefore, minorities must have the goal of achieving equality or equality with the majority.

To date, there is still no common definition of the term 'minority'. However, the most often emphasized problem regarding the existence of minorities is about the fact that any definition of minority must include objective factors (such as the existence of ethnicity, language or religion) and subjective factors (including that individuals must identify themselves as members of a minority). ${ }^{38}$ The difficulty in determining universally accepted minority understandings lies in the diversity of situations in the lives of minorities. Some minorities live together in a recognized area, separate from the dominant part of the population. Some are scattered throughout the country. Some minorities also have a strong sense of collective identity and history; others only maintain their shared inheritance. ${ }^{39}$ The Capotorti's definition is the most acceptable understanding. Therefore, the recognition of minority status is not only determined by the state but must be based on subjective and objective criteria. ${ }^{40}$

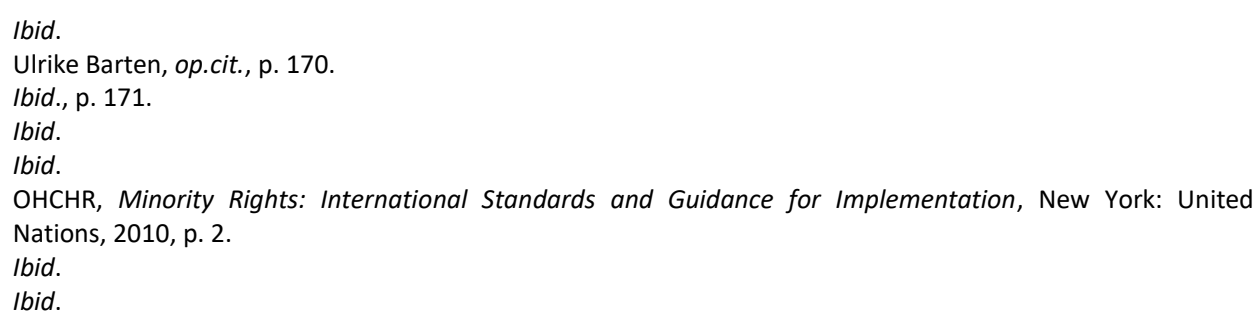




\section{Human Rights Violations against the Uighurs}

\section{Discrimination and Arbitrary Detention}

Based on a report by McDougall in August 2018, there has been arbitrary detention of the Uighurs in Xinjiang, the arrest and detention were carried out to civilians without any apparent reason. It was reported that detention by the Chinese government was only carried out on persons identified as Muslims. They are treated as enemies of the state. ${ }^{41}$ The detainees were then placed in what they called "re-education camps" for political and cultural doctrine. ${ }^{42}$ The aim of the facility seems to be to change the loyalty of the Uighurs to their religion and identity with secular and patriotic political loyalties. ${ }^{43}$ There are reports that more than one million detainees have been placed in re-education camps. ${ }^{44}$ There is no legal basis for the establishment of detention facilities or the detention process carried out by the Chinese government. ${ }^{45}$ They who were transferred to reeducation camps were not tried beforehand. They do not have access to a lawyer, or the right to fight for the detention. ${ }^{46}$ Unused schools, production factories, and prisons are the locations of the re-education camps. ${ }^{47}$

Under Article 9 of the ICCPR, no one can be subject to arbitrary arrest or detention. No one is deprived of his liberty unless the detention process is in accordance with the legal procedures. ${ }^{48}$ Anyone who is arrested must be notified of the time of arrest and the reason of the arrest. ${ }^{49}$ In addition, the Chinese Constitution states that "all ethnic groups in the People's Republic of China are equal". ${ }^{50}$ The Chinese Constitution also prohibits all forms of discrimination and suppresses an ethnic group within its territory. The Chinese Constitution also prohibits acts of discrimination based on religion. ${ }^{51}$ Therefore, arrests and detentions by the Chinese government are not in accordance with the obligations stated in the ICCPR, bearing in mind that these arrests were only based on the cultural and religious identity of the minority.

The Chinese government argues that their actions in the Xinjiang region aim to prevent terrorism and religious extremism. The actions are based on (1) the Counter-Terrorism Law of the People's Republic of China, (2) the Xinjiang Uyghur

41 OHCHR, "Committee on the Elimination of Racial Discrimination reviews the report of China", https://www.ohchr.org/EN/NewsEvents/Pages/DisplayNews.aspx?NewsID=23452\&LangID=E, accessed on August 2018.

42 Ibid.

$43 \quad$ Amnesty International, “China: Where Are They?”, London: Amnesty International Ltd., 2018, p. 13.

44 Ibid., see also Adrian Zenz, "New Evidence for China's Political Re-Education Campaign in Xinjiang", Jamestown Foundation China Brief, 2018; Concluding Observations of UN Committee on the Elimination of Racial Discrimination: China, UN Doc. CERD/C/CHN/CO/14-17, p. 40.

45 Ibid.

$46 \quad$ Ibid

$47 \quad$ Adrian Zenz, loc.cit.

48 Article 9 (1) of International Covenant on Civil and Political Rights.

Article 9 (2) of International Covenant on Civil and Political Rights.

Article 4 of Chinese Constitution.

Article 36 of Chinese Constitution. 
Autonomous Region Implementing Measures for the Counter-Terrorism Law of the People's Republic of China, (3) the Xinjiang Uyghur Autonomous Region Regulation on De-Extremification, and some other regulations. ${ }^{52}$ The detention aims to educate detainees who are identified as people who have been instigated, forced, or even participated in some terrorism or religious extremism activities. ${ }^{53}$ The statement refers to the Urumqi riots in 2009 had a considerable impact on the breakup of relations between ethnic Uighurs and Han ethnicities. ${ }^{54}$ The riots occurred because of acts of violence carried out by the police to stop one of the masses in a peaceful protest being carried out by the Uighurs to the Chinese government. ${ }^{55}$ After that, the Uighurs began to resort to violence by attacking Han's ownership shops, throwing stones and bottles at the police, to attacking pedestrians and taxi and bus drivers. ${ }^{56}$ The riots only began to subside the next day when additional security forces such as police, military police, and military members entered the city of Urumqi. ${ }^{57}$

On July 7, 2009, a group of Hans began to take actions of 'retaliation' against the Uighurs by attacking the Uighurs who were scattered in the city of Urumqi. Chinese authorities report that the incident claimed 197 lives; and 156 of whom were the Han, Hui, Uighur, and Manchu groups. ${ }^{58}$ Responding to the riots, the Chinese government states that the riots started because of the separatist movement that was organized by several separatist groups in Xinjiang. ${ }^{59}$ The Human Rights Watch stated that the root cause of the protests and riots lies in the discriminatory policies by the Chinese government towards the Uighurs. ${ }^{60}$

There are several other reports that there have been other violent incidents after the riots in Urumqi 2009. In 2014, there a market in Urumqi was bombed. Some reports mention that the incident was an act of terrorism. ${ }^{61}$ The Chinese government blames the East Turkistan Islamic Movement (ETIM) and other Uighur

52 HRIC Translation: China's Follow-up Response to UN Committee on the Elimination of Racial Discrimination, https://www.hrichina.org/en/press-work/hric-bulletin/hric-translation-chinas-follow-response-un-

committee-elimination-racial, accessed on December 2019.

53 Ibid.

54 Avinash Godbole and Akash S. Goud, China's Xinjiang Problem: The 2009 Riots and its Aftermath, New Delhi: Institute for Defence Studies \& Analyses, 2012, p. 5.

55 Anna Hayes dan Michael Clarke, Inside Xinjiang: Space, Place and Power in China's Muslim Far Northwest, New York: Routledge, 2016, p. 40.

56 Ibid.

57 Human Rights Watch, China: "We Are Afraid to Even Look for Them": Enforced Disappearances in the Wake of Xinjiang's Protests, 20 October 2009, https://www.hrw.org/report/2009/10/20/we-are-afraid-even-lookthem/enforced-disappearances-wake-xinjiangs-protests, accessed on December 2019.

58 Ibid.

59 Gardner Bovingdon, The Uyghurs: Strangers in Their Own Land, New York: Columbia University Press, 2010, p. 170.

60 M. Rayila, "The Pain of a Nation: The Invisibility of Uyghurs in China Proper," The Equal Rights Review, Volume 6, 2011, p. 44.

61 Human Rights Watch, "Eradicating Ideological Viruses", loc.cit. 
organizations for these acts of terrorism. ${ }^{62}$ The Turkistan Islamic Party (TIP), which is often seen as part of ETIM, has claimed that they are responsible for the bombings that took place in Urumqi. ${ }^{63}$ In addition, there is a report stating that some Uighurs have joined extremist groups in Syria, and the TIP, which has allied itself with Al-Qaeda, has established a new branch in Syria. ${ }^{64}$ On the one hand, the Chinese government continuously tries to influence foreign governments and intergovernmental institutions to label terrorists to ETIM and other Uighur organizations. $^{65}$ The Chinese government's fear of the existence of the organization, acts of terrorism, and religious extremism carried out by several ethnic Uighurs led the Chinese government to issue a new policy. This caused the Chinese government to implement the Strike Hard Campaign policy, and arrests people who were identified as Uighurs.

\section{Freedom of Religion and Expression}

In addition to arbitrary arrests in the implementation of the Strike Hard Campaign, Chinese authorities have long imposed extensive restrictions on religious practices, especially in Xinjiang. The restriction imposed by the Chinese government on Islamic religious practices or teachings in Xinjiang is one of the most stringent and comprehensive restrictions. ${ }^{66}$ The form of limiting Islamic religious practices in Xinjiang was clearly seen when the Chinese government amended the 1994 Regulations of the Xinjiang Uyghur Autonomous Region on Religious Affairs. ${ }^{67}$ In addition, several mosques in Xinjiang were destroyed, Islamic religious symbols such as stars and crescent at burial sites was abolished, and equipment for worship such as prayer mats and the Koran had been confiscated. ${ }^{68}$

Apart from this, the Uighurs were forced to refrain from practicing their religious practices such as the five-time prayer, both in the mosque and at home. ${ }^{69}$ This happens because of pressure from the Chinese authorities. if they find out that a part of the Uighurs practices their religion, they will be arrested and placed in "reeducation camps". ${ }^{70}$ Even in the holy month of Ramadan, Chinese authorities conduct surveillance of people who perform the meal by watching their home lights. If they take meal, the police will visit the house and give them a warning. ${ }^{71}$ Detainees who are in "re-education camps" are also not allowed to carry out

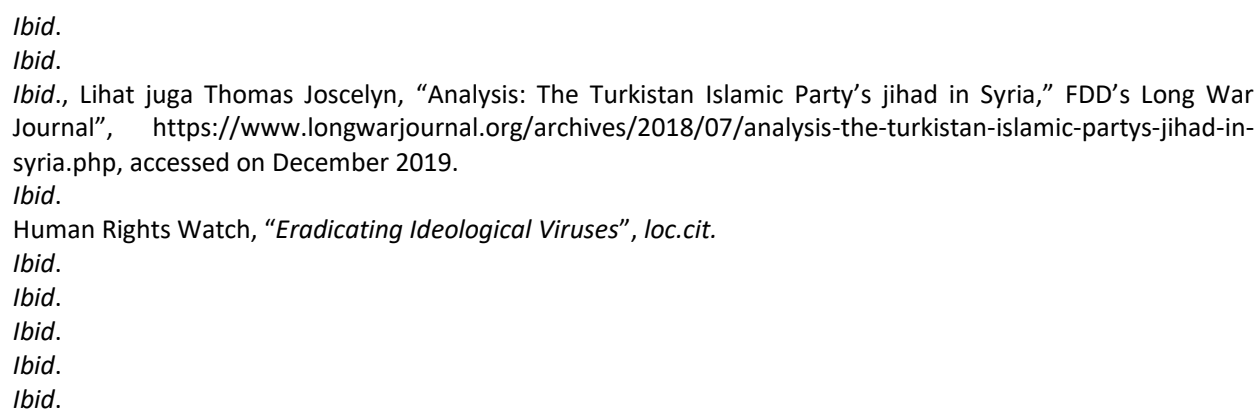


Islamic religious practices such as prayer, fasting, reading the Koran, and even to grow a beard. ${ }^{72}$ Worse, Muslims are forced to drink liquor and eat pork, both of which prohibited in Islam. ${ }^{73}$ The UDHR and the ICCPR guarantee everyone's right to freedom of thought and freedom of religion. These rights include the freedom to own or adopt a religion of one's choice and the freedom to practice one's religious practices or beliefs, either individually or in a group, either privately or publicly. ${ }^{74}$ In addition, the Chinese Constitution also guarantees everyone the right to freedom of expression, including the right to assemble and associate. ${ }^{75}$

\section{Absence of Special Protection for the Minorities}

Article 27 of the ICCPR gives obligations to the state to protect the rights of minorities based on ethnicity, religion, or language so that they can continue to practice their own culture, carry out their religious activities, or use their language. ${ }^{76}$ In its development, the Declarations on Minorities ${ }^{77}$ also mentioned the special rights possessed by minorities. The declaration regulates that the state must give protection to guarantee existence and identity of minority based on their ethnicity, culture, religion, and language. ${ }^{78}$ It also states that minorities have the right to adhere and practice their religion ${ }^{79}$, the right to participate in their religious life $^{80}$, the right to establish and maintain their groups ${ }^{81}$, the right to exercise their rights without discrimination individually or in-groups. ${ }^{82}$

The Declaration on Minorities states that state must take the steps necessary to ensure that persons identified as minorities can exercise all their human rights and basic freedoms without discrimination. ${ }^{83}$ State also has an obligation to take the steps necessary to create favorable conditions for minorities so that they can

\footnotetext{
Ibid.
}

Ibid.

74 Article 18 of Universal Declaration of Human Rights, Article 18-19; International Covenant on Civil and Political Rights.

75 Article 35 of Chinese Constitution.

76 Article 27 of International Covenant on Civil and Political Rights.

77 Resolution adopted by the General Assembly, Declaration on the Rights of Persons Belonging to National or Ethnic, Religious and Linguistic Minorities, 47 th session, A/RES/47/135, December 18, 1992.

78 Article 1 of Declaration on the Rights of Persons Belonging to National or Ethnic, Religious and Linguistic Minorities.

79 Article 2 (1) of Declaration on the Rights of Persons Belonging to National or Ethnic, Religious and Linguistic Minorities.

80 Article 2 (2) of Declaration on the Rights of Persons Belonging to National or Ethnic, Religious and Linguistic Minorities.

81 Article 2 (4) of Declaration on the Rights of Persons Belonging to National or Ethnic, Religious and Linguistic Minorities.

82 Article 3 of Declaration on the Rights of Persons Belonging to National or Ethnic, Religious and Linguistic Minorities.

83 Article 4 (1) of Declaration on the Rights of Persons Belonging to National or Ethnic, Religious and Linguistic Minorities. 
express their identities and to develop their culture, language, religion, traditions, and customs. ${ }^{84}$

In reality, the implementation of the Strike Hard Campaign policy is inversely proportional to the Declaration on Minorities. One proof is the amendment to the Regulations of the Xinjiang Uyghur Autonomous Region on Religious Affairs so that the Muslim minority in Xinjiang cannot performed their religious activities. On the other hand, continued strict supervision by the Chinese authorities on ethnic Uighurs creates adverse conditions for ethnic Uighurs. ${ }^{85}$ The Chinese Authorities are closely watching ethnic Uighurs using digital surveillance systems. Even the Chinese government has placed spies in Xinjiang, causing anxiety and suspicion in some communities. ${ }^{86}$

\section{Efforts to Resolve Human Rights Violations in the Case of Uighurs of Xinjiang 1. Inter-State Complaints Mechanism}

The procedure of Inter-State Complaints can be carried out because the human rights convention creates a legal obligation of the state party to protect the rights of its citizens, so the states parties to the convention have a legal commitment to the other party states to guarantee their citizens the right to rights contained in the agreement. $^{87}$ Therefore, if a state party has evidence that the other party has committed a violation of human rights, then the party has the right to make complaints of human rights violations because state party violation means a failure to respect its commitment to the state other party state. ${ }^{88}$ Therefore, complaints of human rights violations cannot be said to be interventions or interference on the sovereignty of other states, because the binding of a state to a human rights treaty is the same thing as the acceptance of external interference in matters that were once domestic. ${ }^{89}$ In short, this is justification related to complaints of reporting human rights violations by the state.

Based on the provisions contained in the ICCPR, the Committee is an expert body established to monitor the implementation of the provisions contained in the ICCPR in the territory of the state party. ${ }^{90}$ One of the activities of the Committee is to examine the reports submitted by the ICCPR state party ${ }^{91}$ every five years. Each state party has an obligation to provide a report on the steps they have taken that could affect the fulfillment of the rights of its citizens. ${ }^{92}$ The contents of the report

\footnotetext{
84 Article 4 (2) of Declaration on the Rights of Persons Belonging to National or Ethnic, Religious and Linguistic Minorities.

85 Human Rights Watch, "Eradicating Ideological Viruses", loc.cit.

$86 \mathrm{Ibid}$.

87 Scott Leckie, "The Inter-State Complaint Procedure in International Human Rights Law: Hopeful Prospect or Wishful Thinking?", Human Rights Quarterly, Volume 10, Issue 2, 1988, p. 256.

Ibid.

Ibid.

Article 40 (1) of International Covenant on Civil and Political Rights.

Ibid.

Ibid.
} 
are the legislative steps and implementation of the provisions adopted by the state party, regarding the rights recognized in the ICCPR. The report must indicate the factors and difficulties affecting the application of the ICCPR. ${ }^{93}$ Considering that human rights violations committed by China constitute violations of civil and political rights of the Uighurs, therefore, other ICCPR state parties should be able to make complaints of human rights violations committed by China against the Committee.

One legal basis for filing inter-state complaints in the ICCPR is the belief of a state that another party state of the ICCPR does not fulfill the obligations listed in the ICCPR. Article 41 of the ICCPR reads "... not fulfilling its obligations under the present Covenant". In this case, the Chinese government has failed to carry out its obligations in accordance with the Articles 2, 9, 12, 18, and 27 of the ICCPR. However, the procedure for complaints of human rights violations and resolutions carried out by the Human Rights Committee cannot be carried out because, up to now, the Chinese government has not made a declaration or statement that acknowledges that China has recognized the competence of the Human Rights Committee. ${ }^{94}$

Article 41 of the ICCPR which states that "no communication shall be received by the Committee if it concerns a State Party which has not been made such as a declaration". In other words, states parties that have made a declaration or statement that they recognize the competence of the Human Rights Committee can only carry out the procedure for complaints of human rights violations and the settlement set forth in the ICCPR. ${ }^{95}$

Not much different from the ICCPR, the ICERD Convention also gave a mandate to the state party to form an oversight body for the implementation of ICERD called the Committee on the Elimination of Racial Discrimination (CERD Committee). ${ }^{96}$ States parties to ICERD must also submit a report to the UN Secretary-General regarding the steps they have taken in carrying out the obligations stated in ICERD. ${ }^{97}$ Then the CERD Committee will consider the reports and will provide advice to the relevant state parties on the implementation of ICERD.

In this case, the Chinese government has violated the Uighurs' rights contained in the ICCPR. It cannot be denied that the main factor of the violations was discrimination. This can be proven by the existence of special policies aimed only at the Uighurs and the Muslims in Xinjiang. In addition, Gay McDougall, a member of the CERD Committee has reported that ethnic minorities are the Uighurs and the

\footnotetext{
93 International Covenant on Civil and Political Rights, Article 40 (2).

94 United Nations Human Rights Office of the High Commissioner, "Status of Ratification Interactive Dashboard," https://indicators.ohchr.org/, accessed on December 2019.

95 Article 41 of International Covenant on Civil and Political Rights.

96 Article 8 of International Convention on the Elimination of All Forms of Racial Discrimination.

97 Article 9 of International Convention on the Elimination of All Forms of Racial Discrimination.
} 
Muslims are considered enemies of the state. ${ }^{98}$ The Chinese government has also amended several legal regulations designed to enable greater surveillance of ethnic Uighurs. The amended regulations are the 2015 National Security Law, the 2016 Counter-Terrorism Law, the 2017 Cybersecurity Law, and the Religious Affairs Regulations Law. ${ }^{99}$ The report can be used as a basis that the actions taken by the Chinese government in Xinjiang constitute acts of discrimination against ethnic Uighurs.

A state party to ICERD, under Article 11 of the ICERD, can carry out the interstate complaint procedure. When a state party declares that the other party does not fulfill the obligations set out in ICERD, they can submit the matter to the CERD Committee. ${ }^{100}$ Within a period of three months, the recipient state must provide a report to the CERD Committee regarding clarification or clarification statements on the matter. ${ }^{101}$ If the problem cannot be resolved, by either bilateral negotiations or other procedures, then within six months after the receipt of the initial report, both countries have the right to submit the matter again to the CERD Committee. ${ }^{102}$ The Committee can only consider the problem report when all domestic settlement efforts have been made. ${ }^{103}$ The CERD Committee may summon the parties of interest to request relevant information. ${ }^{104}$

The ICERD inter-state complaint procedure is one of the most workable mechanisms for resolving human rights violations in this case, considering that China has ratified and become a state party of ICERD. ${ }^{105}$ The foundation for carrying out inter-State complaint procedures is listed in Article 11 of ICERD, “... if another State Party is not giving effect to the provisions of the convention". It is one of the elements that must be fulfilled in the complaint procedure. China does not carry out the obligations stated in the ICERD convention. Therefore, the element has been fulfilled. In summary, the duties and authority of the CERD Committee are limited to submitting the complaint report to the offending country. ${ }^{106}$ Then, the offending country must submit an explanation or written statement of alleged violations of obligations committed by that country. ${ }^{107}$ If both parties have not yet reached satisfaction, then the matter can be raised again to the CERD

\footnotetext{
98 United Nations Human Rights Office of the High Commissioner, Committee on the Elimination of Racial Discrimination reviews the report China, https://www.ohchr.org/EN/NewsEvents/Pages/DisplayNews.aspx?NewsID=23452\&LangID=E, accessed on October 2019.

$99 \quad$ lbid.

100 Article 11 (1) of International Convention on the Elimination of All Forms of Racial Discrimination.

101 lbid.

102 Article 11 (2) of International Convention on the Elimination of All Forms of Racial Discrimination.

103 Article 11 (3) of International Convention on the Elimination of All Forms of Racial Discrimination.

104 Article 11 (4) of International Convention on the Elimination of All Forms of Racial Discrimination.

105 United Nations Human Rights Office of the High Commissioner, Status of Ratification Interactive Dashboard, https://indicators.ohchr.org, accessed on October 2019.

106 Article 11 (1) of International Convention on the Elimination of All Forms of Racial Discrimination.

107 lbid.
} 
Committee. ${ }^{108}$ Afterwards, if the CERD Committee considers the problem raised by the reporting country, both parties must send their representatives to attend the hearing of the CERD Committee. ${ }^{109}$

The purpose of the creation of such a mechanism is to maintain a problem of human rights violations at the lowest level. ${ }^{110}$ For example, when there is a human rights violation of the provisions contained in ICERD, the first form of settlement must be carried out by states is the mechanism of the CERD Committee. In theory, there are several good reasons to include the complaint mechanism in ICERD, which with the inter-state complaint procedure, there will be a number of options that can be made by the state to resolve discrimination problems committed by ICERD states against their own citizens. However, in practice, the inter-state complaint procedure is difficult because of fears that the reporting country will get criticism of its record of accomplishment in past human rights management efforts. In addition, ${ }^{111}$ it will be difficult to prove that all groups of people who are in the territory of a country receive equal rights de jure and de facto without discrimination. ${ }^{112}$

Although most of the human rights violations committed by the Chinese government violating the provisions of the ICCPR, it should also be noted that the basic and initial intention of the violation is discrimination. The formation of some special policies in Xinjiang by the Chinese government is a proof that China has committed acts of discrimination, coupled with the fact that these policies reject the equality of rights of Uighurs.

This study is in the position that, for the time being, the inter-state complaint procedure is one of the most appropriate efforts to stop human rights violations that occur in China without violating their sovereignty. The failure of China to carry out obligation to comply with the provisions in ICERD is one of the grounds that other ICERD state parties can submit inter-state complaints. If the Chinese government in the next few years does not carry out the recommendations of the CERD Committee in 2018 , another party may make the inter-State complaint. If the peaceful solution recommendations issued by the CERD Committee on complaints of violations are not carried out also by China, then, based on Article 22 of ICERD, the state can bring the matter before the International Court of Justice to be decided later. ${ }^{113}$

These forms of complaints are one way that can be done to deal with human rights issues in other states. However, the practices show that states prefers to

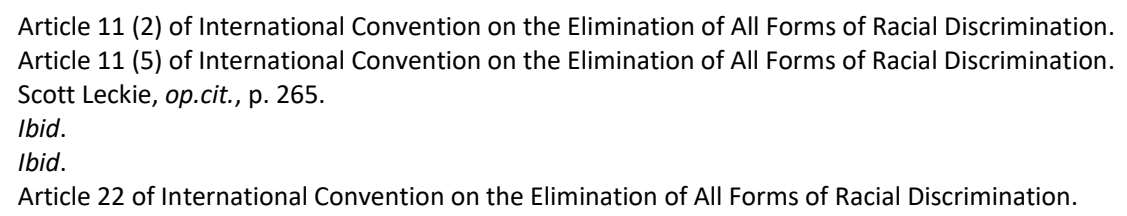


adopt other methods that are acceptable to all parties. ${ }^{114}$ Therefore, most states prefer to engage in forms of diplomacy to increase respect for human rights in general, while at the same time reducing the potential for damage to economic and political relations with other states. ${ }^{115}$ State practices show that the protection of human rights in other states is unimportant compared to their political and economic relations. ${ }^{116}$

Besides political and economic relations between countries, there are other factors for the rare inter-state complaints. An inter-state complaint requires a long time and a significant use of resources, such as (1) intensive legal facts search; (2) sufficient administrative and parliamentary support; (3) good planning and coordination efforts between various branches of government; and (4) continued involvement in the procedure in all aspects, including oral hearings, written submissions, diplomatic contacts with the offending country, and monitoring activities after the case ends. ${ }^{117}$

\section{E. Conclusion}

International law provides protection for minorities in Article 27 of the ICCPR and the Declaration on Minorities. Both instruments state that minorities living in an area of a state must be protected by creating conditions and situations that are conducive so that they can express their language, culture, and religion without pressure from their own government. The state also has an obligation not to discriminate and to guarantee equal rights between minorities and the majority living in their territory. However, actions taken by the Chinese government against the Uighurs strongly contradict the concept of human rights protection of minorities in international law since there are several policies to eliminate cultural, religious, and linguistic identity of the Uighurs of Xinjiang.

Because of all violations committed by China, according to international law, the Chinese government must carry out the state's responsibility to stop human rights violations that occurred in Xinjiang. There are several efforts that can be done by countries that have an interest in protecting the rights of the ethnic minority Uighurs. First, the state can report human rights violations to the CERD Committee, in accordance with Article 11 of the ICERD. After that, the CERD Committee will provide a peaceful solution to resolve all violations committed by China. Second, as a form of responsibility from China for its actions, the Chinese government should punish Chen Quanguo as the executor of Chinese policies in Xinjiang who has prevented the Uighurs from their minority rights.

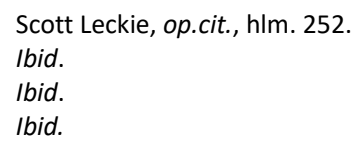




\section{References}

\section{Books}

Amnesty International, China: Where Are They?, Amnesty International Ltd., London, 2018.

Barten, Ulrike, Minorities, Minority Rights and Internal Self-Determination, Springer, New York, 2015.

Bovingdon, Gardner, The Uyghurs: Strangers in Their Own Land, Columbia University Press, New York, 2010.

Capotorti, Francesco, Study on the Rights of Persons Belonging to Ethnic, Religious and Linguistic Minorities, UN Human Rights Study, New York, 1991.

Eide, Asbjorn, A New Approaches to Minority Protection, Minority Rights Group, London, 1993.

Godbole, Avinash, dan Akash S. Goud, China's Xinjiang Problem: The 2009 Riots and its Aftermath, Institute for Defence Studies \& Analyses, New Delhi, 2012.

Hayes, Anna, dan Michael Clarke, Inside Xinjiang: Space, Place and Power in China's Muslim Far Northwest, Routledge, New York, 2016.

Miriam Budiarjo, Dasar-Dasar Ilmu Politik, Jakarta, Gramedia, 1998.

OHCHR, Minority Rights: International Standards and Guidance for Implementation, United Nations, New York, 2010.

\section{Other Documents}

Concluding Observations of UN Committee on the Elimination of Racial Discrimination: China, UN Doc. CERD/C/CHN/CO/14-17.

Deschenes, Jules, Compilation of Proposals Concerning a Definition of the Term "Minority", Commission on Human Rights, 1986.

HRIC Translation: China's Follow-up Response to UN Committee on the Elimination of Racial Discrimination, https://www.hrichina.org/en/press-work/hricbulletin/hric-translation-chinas-follow-response-un-committee-eliminationracial, accessed on December 2019.

Human Rights Watch, China: "We Are Afraid to Even Look for Them": Enforced Disappearances in the Wake of Xinjiang's Protests," https://www.hrw.org/report/2009/10/20/we-are-afraid-even-look-

them/enforced-disappearances-wake-xinjiangs-protests, accessed on December 2019.

Human Rights Watch, "Eradicating Ideological Viruses: China's Campaign of Repression against Xinjiang's Muslim", https://www.hrw.org/report/2018/09/09/eradicating-ideologicalviruses/chinas-campaign-repression-against-xinjiangs, accessed on September 2019. 
Human Rights Watch, "UN: Unprecedented Joint Call for China to End Xinjiang Abuses", https://www.hrw.org/news/2019/07/10/un-unprecedented-joint-callchina-end-xinjiang-abuses, accessed on 2 September 2019.

Human Rights Watch, "World Report 2019: China Events of 2018", https://www.hrw.org/world-report/2019/country-chapters/china-and-tibet, accessed on December 2019.

Joscelyn, Thomas, "Analysis: The Turkistan Islamic Party's jihad in Syria," FDD's Long War Journal", https://www.longwarjournal.org/archives/2018/07/analysis-the-turkistanislamic-partys-jihad-in-syria.php, accessed on December 2019.

Leckie, Scott, "The Inter-State Complaint Procedure in International Human Rights Law: Hopeful Prospect or Wishful Thinking?", Human Rights Quarterly, Volume 10, Issue 2, 1988.

Macklem, Patrick, "Minority Rights in International Law", Legal Studies Research Series, No. 08-19, University of Toronto Faculty of Law, 2008.

Md. Kamruzzaman and Shashi Kanto Das, "The Evolution of Human Rights: An Overview in Historical Perspective", American Journal of Service Science and Management, Volume 3, Issue 2, 2016.

$\mathrm{OHCHR}$, "Committee on the Elimination of Racial Discrimination reviews the report of China", 13 Agustus 2018, https://www.ohchr.org/EN/NewsEvents/Pages/DisplayNews.aspx?NewsID=234 52\&LangID=E, accessed on September 2019.

$\mathrm{OHCHR}$, "Committee on the Elimination of Racial Discrimination Reviews the Report of China", 13 Agustus 2018.

Papoutsi, Emilia, "Minorities Under International Law: How Protected They Are?", Journal of Social Welfare and Human Rights, Volume 2, Issue 1, 2014.

Rayila, M., "The Pain of a Nation: The Invisibility of Uyghurs in China Proper," The Equal Rights Review, Volume 6, 2011.

Resolution adopted by the General Assembly, Declaration on the Rights of Persons Belonging to National or Ethnic, Religious and Linguistic Minorities, $47^{\text {th }}$ session, A/RES/47/135, $18^{\text {th }}$ December 1992.

United Nations Human Rights Office of the High Commissioner, "Committee on the Elimination of Racial Discrimination reviews the report of China," https://www.ohchr.org/EN/NewsEvents/Pages/DisplayNews.aspx?NewsID=234 52\&LangID=E, accessed on October 2019.

United Nations Human Rights Office of the High Commissioner, Status of Ratification Interactive Dashboard, https://indicators.ohchr.org, accessed on October 2019.

Zenz, Adrian, "New Evidence for China's Political Re-Education Campaign in Xinjiang", Jamestown Foundation China Brief, 2018. 


\section{Law Documents}

Constitution of the People's Republic of China

International Convention on the Elimination of All Forms of Racial Discrimination (ICERD)

International Covenant on Civil and Political Rights (ICCPR)

United Nations Declaration on the Rights of Persons Belonging to National or Ethnic, Religious, Linguistic Minorities

Universal Declaration of Human Rights (UDHR)

Vienna Convention on the Law of Treaties (VCLT) 